\title{
Study of the corrosion products formed on carbon steels in the tropical atmosphere of Panama
}

\author{
J.A. Jaén*, M.S. de Villalaz**, L. de Araque ${ }^{* * *}$ C. Hernández** and A. de Bósquez**
}

Abstract Mössbauer spectroscopy and X-ray powder diffraction (in selected samples) have been used to characterize corrosion products on carbon steels after atmospheric exposure to the tropical Panamanian locations of Panama and Colon, classified according to ISO 9223 as C3 and C5, respectively. Goethite $(\alpha-\mathrm{FeOOH})$ of intermediate particle size $(20-100 \mathrm{~nm})$, lepidocrocite $(\gamma-\mathrm{FeOOH})$, a spinel phase consisting of non-stoichiometric magnetite $\left(\mathrm{Fe}_{3-\mathrm{X}} \mathrm{O}_{4}\right)$ and/or maghemite $\left(\gamma-\mathrm{Fe}_{2} \mathrm{O}_{3}\right)$ and nano-sized particles were identified in the corrosion products. The spinel phase is related to short term atmospheric exposure transforms in time to other corrosion products. The corrosion resistance increased with fraction of goethite following a saturation-type behavior.

Keywords Atmospheric corrosion. Carbon steels. Tropical atmosphere. Corrosion products. Mössbauer spectroscopy.

\section{Estudio de los productos de corrosión de aceros al carbono en la atmósfera tropical de Panamá}

\begin{abstract}
Resumen Se caracterizaron los productos de corrosión de aceros al carbono expuestos a las atmósferas tropicales panameñas localizadas en Panamá y Colón, mediante el uso de la espectroscopia Mössbauer y difracción de rayos-X (en muestras seleccionadas). Las atmósferas se clasifican como C3 y C5, respectivamente, de acuerdo a la norma ISO 9223. Se lograron identificar los compuestos goethita $(\alpha-\mathrm{FeOOH})$ de tamaño de partícula intermedio $(20-100 \mathrm{~nm})$, lepidocrocita $(\gamma-\mathrm{FeOOH})$, una fase de espinela consistente en magnetita no estequiométrica $\left(\mathrm{Fe}_{3-\mathrm{x}} \mathrm{O}_{4}\right)$ y/o maghemita $\left(\gamma-\mathrm{Fe}_{2} \mathrm{O}_{3}\right)$, y nanopartículas. La fase de espinela se puede correlacionar con exposiciones cortas a la atmósfera, transformándose en el tiempo en otros productos de corrosión. La resistencia a la corrosión se incrementa con la cantidad de goethita siguiendo una conducta de saturación.
\end{abstract}

Palabras clave Corrosión atmosférica. Aceros al carbono. Atmósfera tropical. Productos de corrosión. Espectroscopia Mössbauer.

\section{INTRODUCTION}

It is of interest the phase analysis of corrosion products to understand the effect of the environment on the corrosion rate and corrosion mechanisms of steels. In recent years, some studies have been performed on the analysis of rusts from carbon steel exposed to the tropical atmosphere using Mössbauer spectroscopy and several other techniques $^{[1-7]}$.
The usual reported atmospheric corrosion products on iron include $\alpha-\mathrm{FeOOH}$ (goethite) in various degrees of cristallinity, $\beta-\mathrm{FeOOH}$ (akaganeite) in marine environments, $\gamma$ - $\mathrm{FeOOH}$ (lepidocrocite) main component of the initial rust layer, and the spinel phase magnetite $\left(\mathrm{Fe}_{3} \mathrm{O}_{4}\right)$, maghemite $\left(\gamma-\mathrm{Fe}_{2} \mathrm{O}_{3}\right)$ and non-stoichiometric magnetite $\left(\mathrm{Fe}_{3-\mathrm{x}} \mathrm{O}_{4}\right)$.

In the present work, the corrosion products formed on carbon steels exposed to tropical locations of Panama are systematically investigated.

(*) Departamento de Química Física, Facultad de Ciencias Naturales, Exactas y Tecnología. Universidad de Panamá.

$\left.{ }^{* *}\right)$ Centro Experimental de Ingeniería, Universidad Tecnológica de Panamá. 
Table I. Program of exposure to atmospheric corrosion for steel 1020

Tabla I. Programa de exposición para la corrosión atmosférica del acero 1020

\begin{tabular}{cc}
\hline Sample code & $\begin{array}{c}\text { Exposure period } \\
\text { (November-November) }\end{array}$ \\
\hline 1.2 & $1993-1994$ \\
1.3 & $1994-1995$ \\
2.1 & $1992-1994$ \\
3.1 & $1992-1995$ \\
\hline
\end{tabular}

\section{EXPERIMENTAL}

The experimental procedure for the preparation of test specimens and exposure to the atmosphere were described in a previous paper ${ }^{[4]}$. Two types of carbon steels were used, type 1020 and A-36. Corrosion products were collected after exposures to the atmosphere following the programs given in table I and II. The site Panama was located at the University Campus, whereas Colon is in a moderate industrial area near the seashore.

Table III presents the classification of test sites according to environmental levels $\left(\mathrm{SO}_{2}=\right.$ sulphation rate, $\mathrm{Cl}^{-}=$chloride ion level and $t_{w}=$ time of wetness) using ISO $9223^{[8]}$. Corrosion products were separated mechanically before determining corrosion rates (corrosion penetration p) from weight losses ${ }^{[9}$ and 10$]$. They were characterized by conventional constant-acceleration ${ }^{57} \mathrm{Fe}$ Mössbauer spectroscopy at room temperature and some samples at $80 \mathrm{~K}$. The Mössbauer spectra were fitted using the program NORMOS. X-ray powder diffraction (Rigaku diffractometer, Model RTP 300 RC) was used as a complementary technique in the analysis of selected samples.
Table III. Environmental characterization of the two exposure locations

Tabla III. Caracterización ambiental de los dos sitios de exposición

\begin{tabular}{lcccc}
\hline \multirow{2}{*}{ Test Site } & \multicolumn{5}{c}{ ISO category } \\
\cline { 2 - 5 } & $\mathrm{Cl}^{-}$ & $\mathrm{SO}_{2}$ & $\mathbf{t}_{\mathrm{w}}$ & Corrosivity \\
\hline Panama & $\mathrm{S}_{1}$ & $\mathrm{P}_{1}$ & $\tau_{4}$ & $\mathrm{C} 3$ \\
Colon & $\mathrm{S}_{1}$ & $\mathrm{P}_{2}$ & $\tau_{5}$ & $\mathrm{C} 5$ \\
\hline
\end{tabular}

\section{RESULTS AND DISCUSSION}

The results of corrosion rates and losses for both types of steel are summarized in table IV using bilogarithmic relationships. The difference between corrosion rates, specially at early stages, are due to the higher levels of sulphation rate $\left(\left[\mathrm{SO}_{2}\right]\right)$, chloride ion $\left(\left[\mathrm{Cl}^{-}\right]\right)$and time of wetness $\left(t_{w}\right)$ in Colon site as compared to Panama ${ }^{[4}$ and 8$]$.

Representative XRD patterns of corrosion products from A-36 steel are shown in figures 1 and 2. The identified constituents were lepidocrocite $(\gamma-\mathrm{FeOOH})$, goethite $(\alpha-\mathrm{FeOOH})$ and magnetite $\left(\mathrm{Fe}_{3} \mathrm{O}_{4}\right)$. The peak intensity of the diffraction lines attributed to magnetite gradually decreases with exposure time, thus indicating that magnetite is a dominant crystalline constituent at the early stages of atmospheric corrosion in the tropical locations of Panama and Colon. It is important to note that under unfavorable conditions of peak width and intensity, it is difficult to ascertain the presence of magnetite, maghemite or both. Thus, even though we have identified the presence of magnetite, XRD does not exclude the possibility of maghemite. The same constituents were identified in the corrosion products from steel 1020, but the intensity of the magnetite peaks were very much

Table II. Program of exposure to atmospheric corrosion for steel A-36

Tabla II. Programa de exposición para la corrosión atmosférica del acero A-36

\begin{tabular}{cccccccc}
\hline & \multicolumn{2}{c}{ Panama } & \multicolumn{3}{c}{ Colon } \\
\hline Sample code & Starting date & Time of exposure (d) & Sample code & Starting date & Time of exposure (d) \\
\hline P-3-1 & Dec 27-96 & 99 & C-3-1 & Jul & $3-97$ & 102 \\
P-3-2 & Apr $2-97$ & 97 & C-3-2 & Oct $13-97$ & 101 \\
P-3-3 & Jul $7-97$ & 95 & C-3-3 & Jan 22 & 96 & 92 \\
P-3-4 & Oct $10-97$ & 96 & C-3-4 & Apr 28-98 & 94 \\
P-3-5 & Jan $14-98$ & 92 & C-3-5 & Jul 28-98 & 203 \\
P-6 & Dec 27-96 & 196 & C-6 & Jul $3-97$ & 299 \\
P-9 & Dec 27-96 & 291 & C-9 & Jul $3-97$ & 391 \\
P-12 & Dec 27-96 & 387 & C-12 & Jul 3-97 & 485 \\
P-15 & Dec 27-96 & 479 & C-15 & Jul 3-97 & \\
\hline
\end{tabular}


Table IV. Bilogarithmic relationships between penetration values $p(\mu \mathrm{m})$ and exposure time $t$ (years), and their correlation coefficients (C.C.)

Tabla IV. Relaciones bilogarítmicas entre valores de penetración $p(\mu \mathrm{m})$ y el tiempo de exposición + (años), y sus coeficientes de correlación (C.C.)

\begin{tabular}{lccc}
\hline Test site & Substrate & Equation & C.C. \\
\hline \multirow{2}{*}{ Panama } & $\mathrm{A}-36$ & $\ln \mathrm{p}=3.908+0.438 \ln \mathrm{t}$ & 0.991 \\
& 1020 & $\ln \mathrm{p}=3.423+0.576 \ln \mathrm{t}^{*}$ & 0.882 \\
Colon & $\mathrm{A}-36$ & $\ln \mathrm{p}=4.770+0.644 \ln \mathrm{t}$ & 0.986 \\
& 1020 & $\ln \mathrm{p}=4.671+0.590 \ln \mathrm{t}^{*}$ & 0.971 \\
\hline
\end{tabular}

* Includes previous results ${ }^{[4]}$ using the same type of steel, in order to have more significance in the experimental equation.

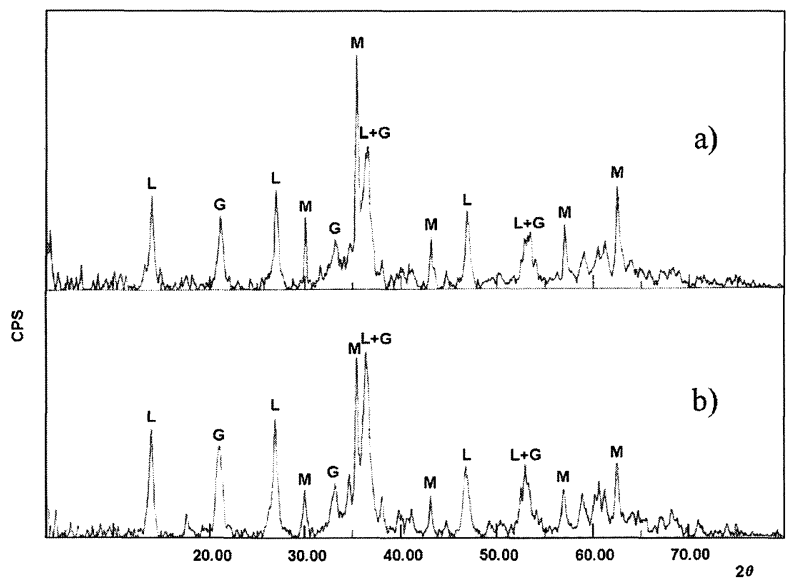

Figure 1. XRD patterns of A-36 steel corroded samples (a) P-3-2 and (b) P-6 exposed at Panama site (monochromatic radiation $\mathrm{Cu}-\mathrm{K} \alpha)$. Descriptions: $\mathrm{L}=$ lepidocrocite, $\mathrm{G}=$ goethite and $M=$ magnetite.

Figura 1. Patrones de difracción de rayos $X$ de muestras de acero A-36 corroído (a) P-3-2 y (b), expuestos en la extación de Panamá (radiación monocromática $\mathrm{Cu}-\mathrm{K \alpha} \alpha$ ). Descriptores: $L=$ lepidocricita, $G=$ Goetita y $M=$ Magnetita.

reduced, indicating lower magnetite content in the rust.

Corrosion products were also characterized using Mössbauer spectroscopy (Figs. 3-4). Figure 3 show the Mössbauer spectra of the adherent rust formed in the 1020 steel in test site Panama. It is worth nothing that adherent and non-adherent rust showed similar Mössbauer spectra. They were fitted to a quadrupole doublet $\left(\delta_{\mathrm{Fe}}=0.34\right.$ $0.41 \mathrm{~mm} \mathrm{~s}^{-1}, \Delta=0.53-0.56 \mathrm{~mm} \mathrm{~s}^{-1}$ and $\Gamma=0.54$. $0.56 \mathrm{~mm} \mathrm{~s}^{-1}$ ) and three sextets with hyperfine magnetic fields, $\mathrm{H}_{1}=49.2-50.0 \mathrm{~T}, \mathrm{H}_{2}=45.9$ $46.6 \mathrm{~T}$ and $\mathrm{H}_{3}=34-36 \mathrm{~T}$. The fit parameters suggested that the corrosion products could

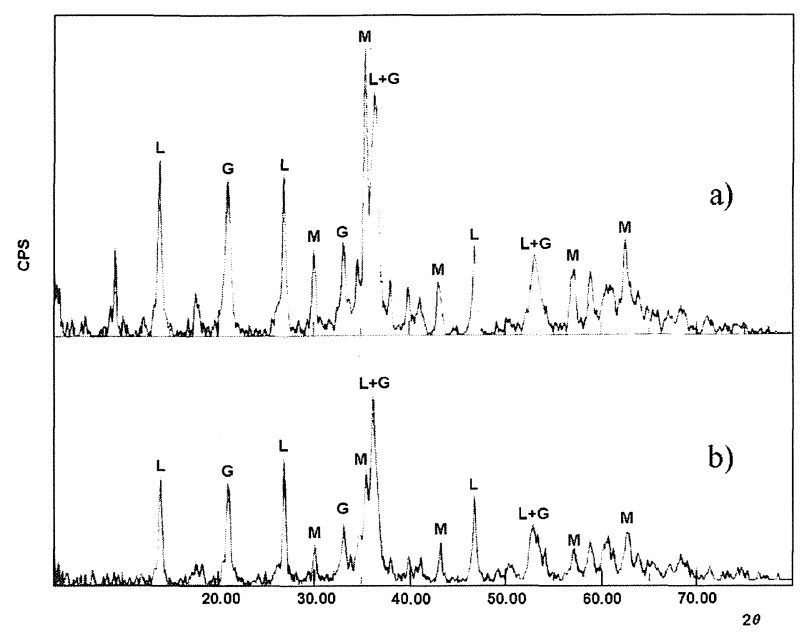

Figure 2. XRD patterns of A-36 steel corroded samples (a) C-3-2 and (b) C-6 exposed at Colon site (monochromatic radiation $\mathrm{Cu}-\mathrm{K} \alpha \mathbf{\alpha})$. Descriptions: $L=$ lepidocrocite, $G=$ goethite and $M=$ magnetite.

Figura 2. Patrones de difracción de rayos $X$ de muestras de acero A-36 (a) P-3-2 y (b) P-6, expuestos en la estación de Colón (radiación monocromática Cu-Ko). Descriptores: $L=$ lepidocrocita, $G=$ goetita y $M=$ Magnetita.

contain lepidocrocite and nano-sized particles. Akaganeite was exclude since it could not be observed in the X-ray analysis and in the $80 \mathrm{~K}$ Mössbauer spectra. Hyperfine magnetic fields $\mathrm{H}_{1}$ and $\mathrm{H}_{2}$ can be ascribed to the spinel non stoichiometric-magnetite $\left(\mathrm{Fe}_{3-\mathrm{X}} \mathrm{O}_{4}\right)$. In some cases, for samples of two or three years exposure only the outer sextet was observed due to the total oxidation to the spinel better characterized as maghemite $\left(\gamma-\mathrm{Fe}_{2} \mathrm{O}_{3}\right)$. The remaining sextet of broad asymmetrical lines has hyperfine parameters corresponding to goethite of intermediate particle size $(20-100 \mathrm{~nm})^{[11]}$.

Figure 4 shows the Mössbauer spectra of the rust formed in the case of steel A-36 in test site Panama, which were deconvoluted practically using the same fitting model; i.e. a quadrupole doublet $\left(\delta_{\mathrm{Fe}}=0.33-0.36 \mathrm{~mm} \mathrm{~s}^{-1}, \Delta=0.57\right.$ $0.62 \mathrm{~mm} \mathrm{~s}^{-1}$ and $\Gamma=0.40-0.47 \mathrm{~mm} \mathrm{~s}^{-1}$ ) and the three sextets assigned to non-stoichiometric magnetite/maghemite and to goethite of intermediate particle size. The slight increase of quadrupole splitting hint to a decrease of the fraction of $\gamma$ $\mathrm{FeOOH}$ phases in the rust. It should be pointed out that the relative amount of the spinel phase is larger at the initial stages of corrosion, but decreases during period of the test.

The Mössbauer spectra of the rust from Colon test site showed a quadrupole doublet with two 

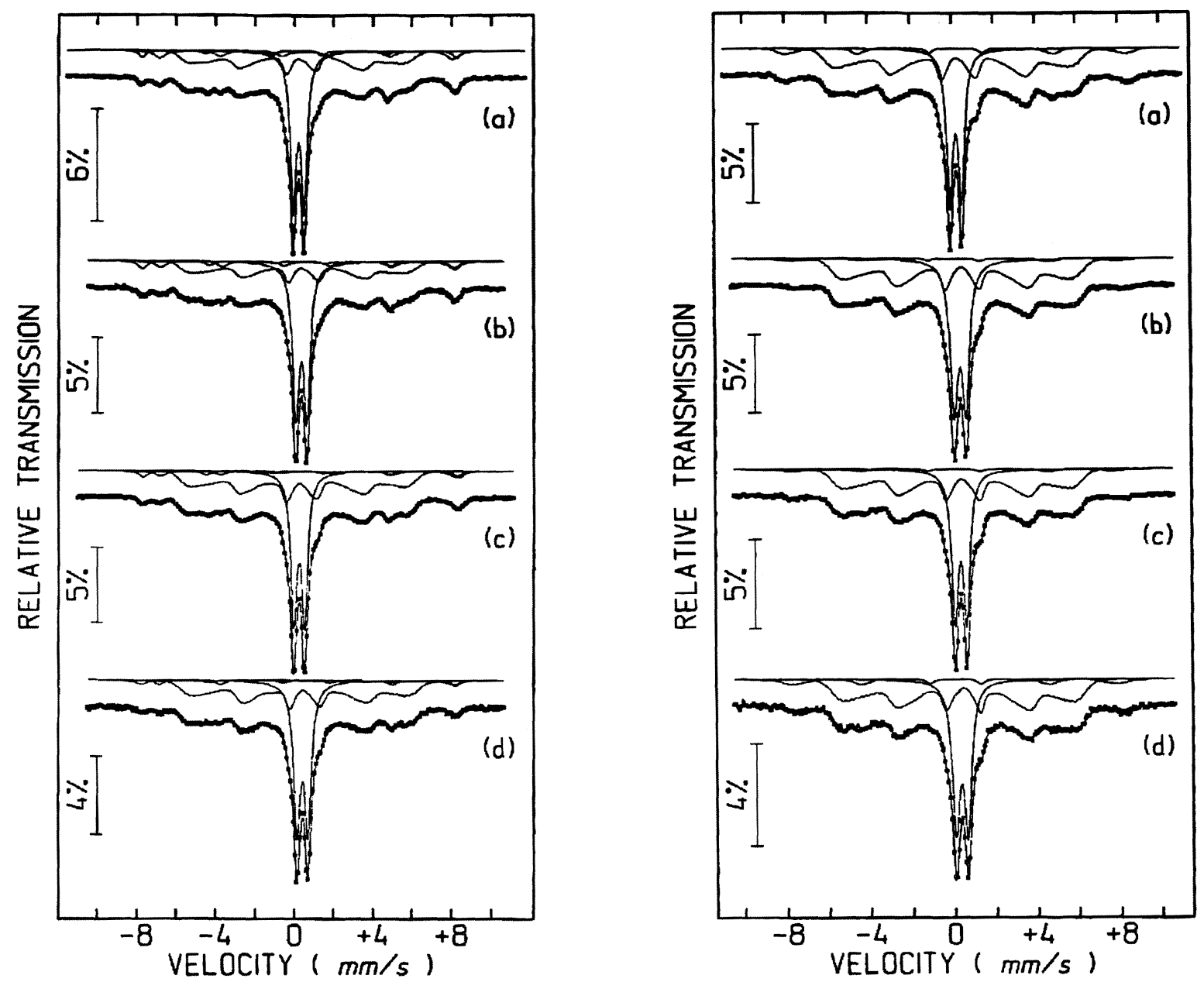

Figure 3. Room temperature Mössbaver spectra of corrosion products of steel 1020 exposed at sites (left) Panama and (right) Colon from samples (a) 1.2, (b) 1.3, (c) 2.1 and (d) 3.1 .

Figura 3. Espectros Mössbaver a temperatura ambiente de los productos de corrosión de un acero 1020 expuesto en las estaciones de Panamá (izquierda) y Colón (derecha), muestras (a) 1.2, (b) 1.3, (c) 2.1 y (d) 3.1.

collapsing sextets fitted as distributions of hyperfine fields, corresponding to lepidocrocite and/or nanosized particles, goethite and a spinel phase. Again, more spinel phase is observed at the beginning of corrosion, diminishing after prolonged exposure to the atmosphere. The shape of the spectra strongly suggests a highly distorted, defective and oxidized spinel structure in the rust from Colon.

In order to know the change of rust composition with exposure period, and the increase of corrosion penetration, a ternary diagram with the fractions (Mössbauer areas) of the three type of corrosion products was used, as seen in figure 5. It is clear that for short exposure periods rust contains large amount of the spinel phase, thus, the initially high corrosion rates could be related to the presence of the spinel phase. Oh et al. ${ }^{[12]}$ related the formation of bulk $\gamma-\mathrm{Fe}_{2} \mathrm{O}_{3}$ to the high corrosion rate of carbon steel. The spinel phase has smaller contributions in the samples of Colon as compared to those of Panama. This was explained elsewhere ${ }^{[4]}$ as due to the high precipitation and humidity (lack of wetdry cycles) prevailing in Colon, but it might be that this phase initially formed as a result of the reduction of rust layer ${ }^{[13]}$, transforming again to $\gamma \mathrm{FeOOH}$ via a solid state reaction. With the decrease of the amount of the spinel phase with exposure period, there is an increment of the other corrosion products, goethite for Panama test site and lepidocrocite (plus nano-sized particles) for Colon. In the latter case, there is also a slight increment of the goethite component.

According to the conclusions of a previous study ${ }^{[4]}$, goethite of intermediate particle size is related to corrosion penetration $(\rho)$ by a saturation t behavior, following a Langmuir type of relationship. 

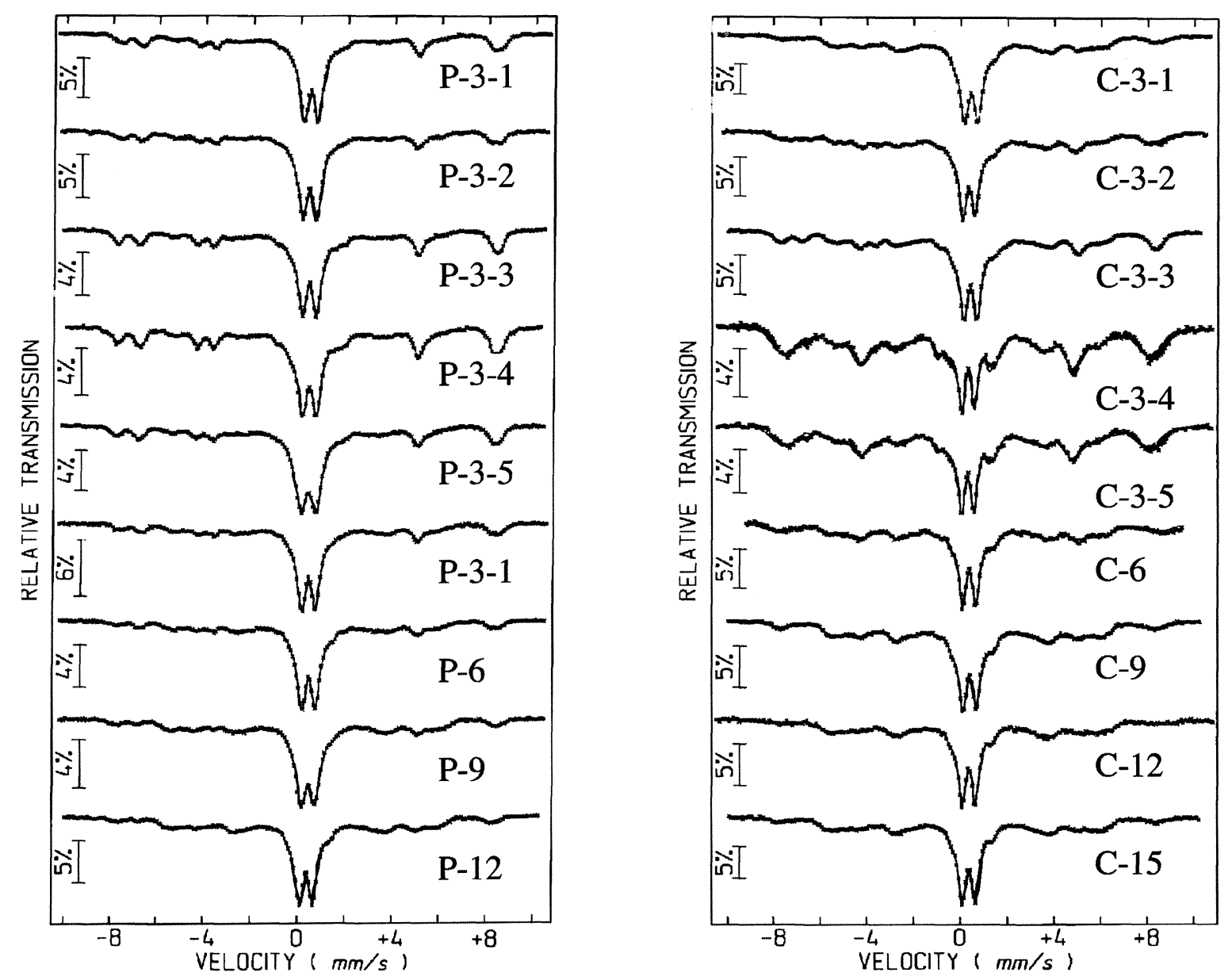

Figure 4. Room temperature Mössbaver spectra of corrosion products of steel A-36 exposed at sites (left) Panama and (right) Colon.

Figura 4. Espectros Mössbaver a temperatura ambiente de los productos de corrosión de un acero A-36 expuesto en las estaciones de Panamá (izquierda) y Colón (derecha).

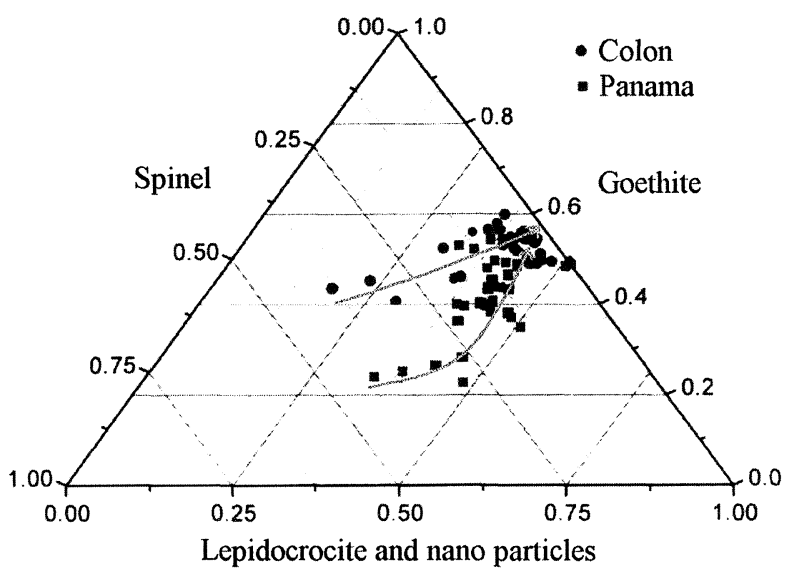

Figure 5. Representation of exposure-time dependence of the corrosion products formed on carbon steels. Exposure time increases along the arrow.

Figura 5. Representación de la dependencia con el tiempo de exposición de los productos formado sobre aceros al carbono. El tiempo de exposición aumenta en el sentido de la flecha.
Using this approach, it could be obtained the relationships $\mathrm{p} / \mathrm{A}_{\mathrm{G}}=0.258+0.0171 \mathrm{p}$ for rust from steel 1020 , and $\mathrm{p} / \mathrm{A}_{\mathrm{G}}=0.492+0.0141 \mathrm{p}$ for steel A-36; here $A_{G}$ es the room temperature Mössbauer area of goethite of intermediate particle size. This goethite confers carbon steel certain degree of protection up to a limit given by the saturation surface coverage by goethite particles.

\section{CONCLUSION}

The main constituents of rust formed on carbon steels 1020 and A-36 after exposure at two sites in the tropical atmosphere of Panama are lepidocrocite, nano-sized particles, goethite of intermediate particle size and a spinel phase.

The spinel phase, consisting of $\mathrm{Fe}_{3-\mathrm{x}} \mathrm{O}_{4} /$ $\gamma-\mathrm{Fe}_{2} \mathrm{O}_{3}$ is related to short term atmospheric exposure. This phase transforms in time to other 
corrosion products. It is proposed that goethite of intermediate particle size gives some corrosion resistance up to a limit given by a saturation of this component on the surface.

\section{REFERENCES}

[1] C. Haces, F. Corvo and A. Pérez Reyes, Rev. CENIC Cienc. Quim. 12 (1981) 55-65.

[2] J.A. JAÉN and B. FERNÁNDEZ, Electrochem. Acta 34 (1989) 885-886.

[3] J.A. Jaén, E. Flórez, A. Valencia, R. Pérez, and C. Arroyave, Anales 4" Congreso Ibero-Americano de Corrosión y Protección, Mar del Plata, Argentina, 1992, pp. 95-101.

[4] J.A. Jaén, M. Sánchez de Villalaz, L. de Araque and A. DE BósQuez, Hyp. Int. 110 (1997) 93-99.

[5] A. Rincón, O.T. de Rincón, C. Haces, N.R. Furet and F. Corvo, Corrosion 53 (1997) 835-841.
[6] D.C. Cook, A.C. van Orden, J.J. Carpio and S.J. Oh, Hyp. Int. 113 (1998) 319-329.

[7] R. Balasubramanian, D.C. CoOk,. T. Pérez and J. Reyes, Hyp. Int. (C) 4 (1999) 37-41.

[8] M. Morcillo, E. Almeida, B. Rosales, J. Uruchurtu and M. Marrocos (eds.), Corrosión y Protección de Metales en las Atmósferas de Iberoamérica. Parte I, $1^{\text {st }}$ edition, Programa CYTED, Spain, 1998, p. 760.

[9] ISO 9226, Corrosion of metals and alloys, , International Standards Organization, Geneve, 1991.

[10] ASTM G1, Preparing, cleaning and evaluating corrosion test specimens, American Society for Testing of Materials, Philadelphia, 1991.

[11] C. Barrero, R. Vandenberghe, E. De Grave and G. PÉREZ, Rev. Col. Fis. 27 (1995) 387-390.

[12] S.J. OH, D.C. CoOK and H.E. Towsend, Hyp. Int. (C) 3 (1998) 84-87.

[13] M. Stratmann and K. Hoffmann, Corros. Sci. 29 (1989) 1.329-1.352. 